\title{
SISTEM INFORMASI KULIAH KERJA NYATA (KKN) BERBASIS ANDROID UNIVERSITAS LAMPUNG
}

\author{
${ }^{1}$ Aristoteles, ${ }^{2}$ Nur Efendi, ${ }^{3}$ Febi Eka Febriansyah, ${ }^{4}$ Wisnu Lukito, ${ }^{5}$ Firmansyah \\ 1,2,3,4,5 Jurusan Ilmu Komputer FMIPA Unila
}

email : ${ }^{1}$ aristoteles.1981@ fmipa.unila.ac.id., ${ }^{2}$ nurefendi10@gmail.com, ${ }^{3}$ febi_ef@yahoo.com,

${ }^{4}$ wisnuluck96@gmail.com, ${ }^{5}$ firmansyah020296@gmail.com

\begin{abstract}
Kuliah Kerja Nyata (KKN) is an University of Lampung intracurricular activity, that not only involving college student, but lecturer themselves as an field supervisor. Along with the advances of technology, Badan Pelaksana Kuliah Kerja Nyata (BP-KKN) necessarily need developing an android based information system, in order to giving practiculary easy and more efficient access towards the information. The purpose of this research is developing an KKN information system based on android for college student, field supervisor coordinator lecturer and field supervisor lecturer.

The system research development is using Incremental method, system development method is based on the software need that divided by three stages that are: requirement analysis, specification and design architecture. Those stages must finished and vitrificated first before continuing to the next stage.

The research produce an KKN information system based on android that applied into smartphones. The conclusion that obtained from this research is successfully build and developed information system that hopefully helping the college student and field advisor lecturer performing an activity that based on information system in the field. This case also strengthened by the result of questionnaire that got very good respond from both college student and field supervisor lecturer.
\end{abstract}

Keywords: Android, College Student, Field Supervisor, KKN, Lecturer, Unila

\section{Pendahuluan}

Kuliah Kerja Nyata (KKN), adalah suatu kegiatan intrakulikuler yang memadukan Tridharma perguruan tinggi yaitu: pendidikan, penelitian, dan pengabdian kepada masyarakat yang dilakukan secara luas antar sektor masalah masing-masing. KKN merupakan proses pengembangan didalam pendidikan tinggi untuk mengasah dan membekali mahasiswa dalam kompetensi sosial. Kegiatan KKN mengharuskan mahasiswa untuk turun secara langsung ke masyarakat dalam maksud untuk menjadi bagian masyarakat, dan mencoba menerapkan ilmu pengetahuan dan pengalaman mahasiswa tersebut untuk memecahkan permasalahanpermasalahan yang dihadapi oleh masyarakat secara akademis. Pelayanan masyarakat merupakan tujuan utama dari kegiatan KKN, dan hal ini menjadikan KKN memiliki peran penting dalam menyiapkan mahasiswa menjadi generasi yang lebih baik dan berkualitas[1].

Universitas Lampung (Unila) ikut menyelenggarakan kegiatan KKN sebagai wujud pengabdian kepada masyarakat. Kegiatan KKN Unila dimasukan kedalam mata kuliah wajib, yang menunjukan bahwa mahasiswa Unila diharuskan melakukan pengabdian terhadap masyarakat daerah. Kegiatan KKN Unila dalam pelaksanaanya dibawahi oleh suatu badan yaitu Badan Pelaksana Kuliah Kerja Nyata.

Pelaksanaan Kuliah Kerja Nyata yang dilaksanakan oleh Badan tersebut saat ini sudah memberikan kemajuan teknologi yaitu dengan menerapkan informasi berupa Sistem Informasi KKN. Sistem tersebut mencakup pelaksanaan Pendaftaran, sampai dengan pelaksanaan Pelaporan yang dilakukan oleh mahasiswa, penetapan lokasi KKN, dan pengelompokan mahasiswa. Dalam 


\section{(C) Ilmu Komputer Unila Publishing Network all right reserve}

kegiatannya, KKN memiliki berbagai unsur lapisan dalam membantu pelaksanaan kegiatannya, dalam hal ini ada Koordinator Dosen Pembimbing Lapangan (KDPL) dan Dosen Pembimbing Lapangan (DPL) dan Mahasiswa. Dengan kemajauan teknologi yang sudah berkembang dengan penggunaan sistem informasi yang dilakukan oleh BP-KKN, masih tidak efisien jika pengguna menggunakan Personal Computer dalam proses pelaksanaan pengelompokkan sampai dengan proses penilaian kegiatan dan pelaporan.

Penelitian dilakukan untuk membuat sistem sistem pelaporan mahasiswa KKN berbasis Android. Sistem pelaporan ini membantu mahasiswa dalam proses pengiriman laporan KKN. Proses pengiriman laporan KKN dapat dilakukan melalui aplikasi yang ada di smartphone. Pemantauan laporan dapat lebih mudah dilakukan melalui aplikasi yang bernama KKNdroid[2]. Namun, aplikasi ini masih memiliki kekurangan seperti fitur belum sesuai dengan yang ada di sistem informasi berbasis web. Oleh karena itu penelitian ini melakukan pengembangan suatu aplikasi berbasis android berdasarkan sistem informasi KKN di BP-KKN. Aplikasi ini diharapkan memberikan kemudahan dalam akses sistem informasi tersebut tanpa mengurangi fasilitas yang ada didalamnya.

\section{Tinjauan Pustaka}

2.1.Kuliah Kerja Nyata

Kuliah Kerja Nyata (KKN) adalah suatu kegiatan intrakulikuler yang memadukan pelaksanaan Tri Dharma Perguruan Tinggi dengan metode pemberian pengalaman belajar dan bekerja kepada mahasiswa dalam kegiatan pemberdayaan masyarakat. Oleh karena itu, KKN diarahkan untuk menjamin keterkaitan antara dunia akademik-teoritik dan dunia empirik-praktis. Paradigma kegiatan KKN harus merespon terhadap tekanan globalisasi saat ini serta peningkatan kualitas hidup masyarakat Indonesia. Oleh sebab itu, program KKN Unila dikembangkan melalui pendekatan pemberdayaan kelompok yang berbasis keluarga, sehingga KKN Unila dinamakan KKN Pemberdayaan Masyarakat dan Pemberdayaan keluarga[3].

\subsection{Android}

Android merupakan OS (Operating System) Mobile yang tumbuh ditengah perkembangan OS lainnya pada masa sekarang ini seperti Windows Mobile, i-Phone OS, Symbian, dan masih banyak lagi. Android OS yang ada ini berjalan dengan memprioritaskan aplikasi inti yang dibangun sendiri tanpa melihat potensi yang cukup besar dari aplikasi pihak ketiga oleh karena itu, adanya keterbatasan dari aplikasi pihak ketiga untuk mendapatkan data asli ponsel, berkomunikasi antar proses serta keterbatasan distribusi aplikasi pihak ketiga untuk platform mereka.

Berdasarkan pendapat diatas, maka dapat ditarik kesimpulan bahwa android adalah sistem operasi berbasis linux yang sedang berkembang ditengah OS lainnya[4].

\subsection{UML (Unified Modeling Language)}

UML (Unified Modeling Language) adalah 'bahasa' pemodelan untuk sistem atau perangkat lunak yang berparadigma 'berorientasi objek". Pemodelan (modeling) sesungguhnya digunakan untuk penyederhanaan permasalahan-permasalahan yang kompleks sedemikian rupa sehingga lebih mudah dipelajari dan dipahami[5].

\subsection{MySQL}

MySQL adalah salah satu jenis database server yang sangat terkenal dan banyak digunakan untuk membangun aplikasi web yang menggunakan database sebagai sumber dan pengolahan datanya[6].

\subsection{Incremental Model}

Model incremental adalah model pengembangan sistem pada software engineering berdasarkan kebutuhan. Incremental model dipilih karena metode ini dapat meminalisir ketidak sesuaian dalam pengembangan perangkat lunak [7]. 


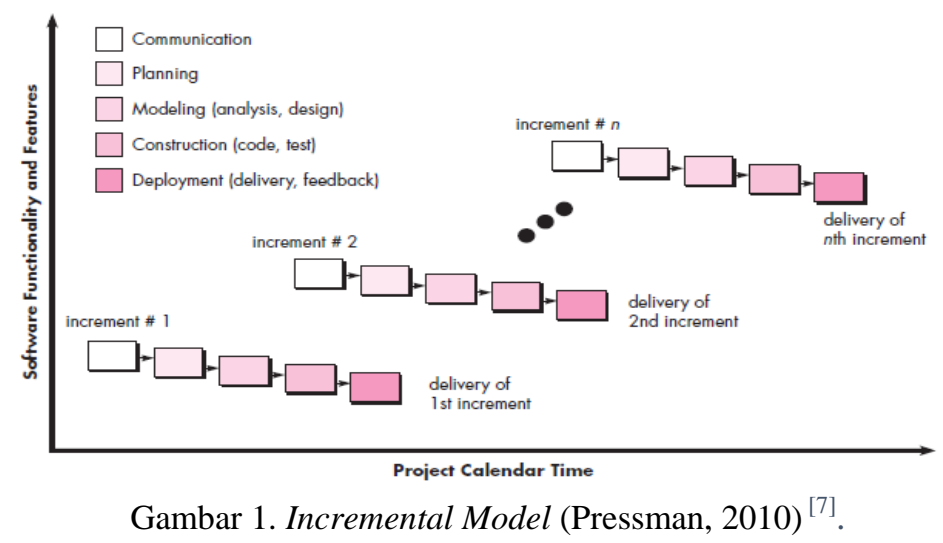

\subsection{Black-Box Testing}

Pendekatan black-box merupakan pendekatan pengujian untuk mengetahui apakah semua fungsi perangkat lunak telah berjalan semestinya sesuai dengan kebutuhan fungsional yang telah didefinisikan. Kasus ini bertujuan untuk menunjukkan fungsi perangkat lunak tentang cara beroperasinya. Teknik pengujian ini berfokus pada domain informasi dari perangkat lunak, yaitu melakukan kasus uji dengan mempartisi domain input dan output program [8].

\subsection{Equivalence Partitioning}

Equivalence Partitioning (EP) merupakan metode black box testing yang membagi domain masukan dari program kedalam kelas-kelas sehingga test case dapat diperoleh. Equivalence Partitioning berusaha untuk mendefinisikan kasus uji yang menemukan sejumlah jenis kesalahan, dan mengurangi jumlah kasus uji yang harus dibuat. Kasus uji yang didesain untuk Equivalence Partitioning berdasarkan pada evaluasi dari kelas ekuivalensi untuk kondisi masukan yang menggambarkan kumpulan keadaan yang valid atau tidak. Kondisi masukan dapat berupa spesifikasi nilai numerik, kisaran nilai, kumpulan nilai yang berhubungan atau kondisi Boolean[9].

\subsection{Skala Likert}

Skala Likert merupakan metode pengukuran yang digunakan untuk mengukur sikap, pendapat dan persepsi seseorang atau kelompok orang tentang fenomena sosial. Skala pengukuran untuk tingkat kepuasan 1 (Sangat Baik), 2 (Baik), 3 (Cukup Baik), 4 (Kurang Baik) dan 5 (Tidak Baik)[10].

\section{Metodologi}

Dalam pengembangan aplikasi ini, digunakan model incremental. Software yang dipecah menjadi beberapa fungsi atau bagian sehingga model pengembangannya secara bertahap. Pendapat lain mengartikan model incremental sebagai perbaikan dari model waterfall dan sebagai standar pendekatan topdown.

1. Requirement, Requirement adalah proses tahapan awal yang dilakukan pada incremental model adalah penentuan kebutuhan atau analisis kebutuhan.

2. Specification, Specification adalah proses spesifikasi dimana menggunakan analisis kebutuhan sebagai acuannya.

3. Architecture Design, adalah tahap selanjutnya, perancangan software yang terbuka agar dapat diterapkan sistem pembangunan per-bagian pada tahapan selanjutnya.

4. Code setelah melakukan proses desain selanjutnya ada pengkodean.

5. Test merupakan tahap pengujian dalam model ini.

\section{Pembahasan \\ 4.1.Analisa Kebutuhan Data}


Data yang dibutuhkan dalam aplikasi Android ini meliputi data DPL, KDPL dan Mahasiswa. Data yang dibutuhkan tersebut diperoleh dari Sekretariat KKN Unila. Data aplikasi ini didasarkan dari data KKN periode I 2018 yaitu sebanyak 16 KDPL, 56 DPL, 2725 Mahasiswa, dan 389 Desa. Data ini digunakan untuk menguji sistem sebagai pengguna aplikasi yang sudah terdaftar didalam sistem KKN dan mendapatkan token login untuk aplikasi ini. Data DPL dan KDPL digunakan untuk mendapatkan informasi mengenai biodata, lokasi penempatan KKN dan mahasiswa bimbingannya. Data Mahasiswa digunakan untuk mendapatkan informasi mengenai biodata, lokasi penempatan KKN, laporan pelaksana dan nilai KKN.

Tabel 1. Data Mahasiswa Peserta KKN Periode 1 Tahun 2018

\begin{tabular}{llll}
\hline Fakultas & Peserta Pria & Peserta Wanita & Jumlah \\
\hline Ekonomi & 124 & 225 & 349 \\
\hline Hukum & 215 & 179 & 394 \\
\hline ISIP & 187 & 349 & 536 \\
\hline Kedokteran & 46 & 131 & 177 \\
\hline KIP & 1 & 0 & 1 \\
\hline MIPA & 52 & 125 & 177 \\
\hline Pertanian & 294 & 444 & 738 \\
\hline Teknik & 234 & 119 & 353 \\
\hline Total Peserta & $\mathbf{1 1 5 3}$ & $\mathbf{1 5 7 2}$ & $\mathbf{2 7 2 5}$ \\
\hline
\end{tabular}

\subsection{Implementasi Sistem}

Tahap impelemtasi merupakan hasil dari perancangan sistem. Berikut beberapa tampilan halaman antar muka pada aplikasi Sistem Informasi KKN Universitas Lampung Berbasis Android.

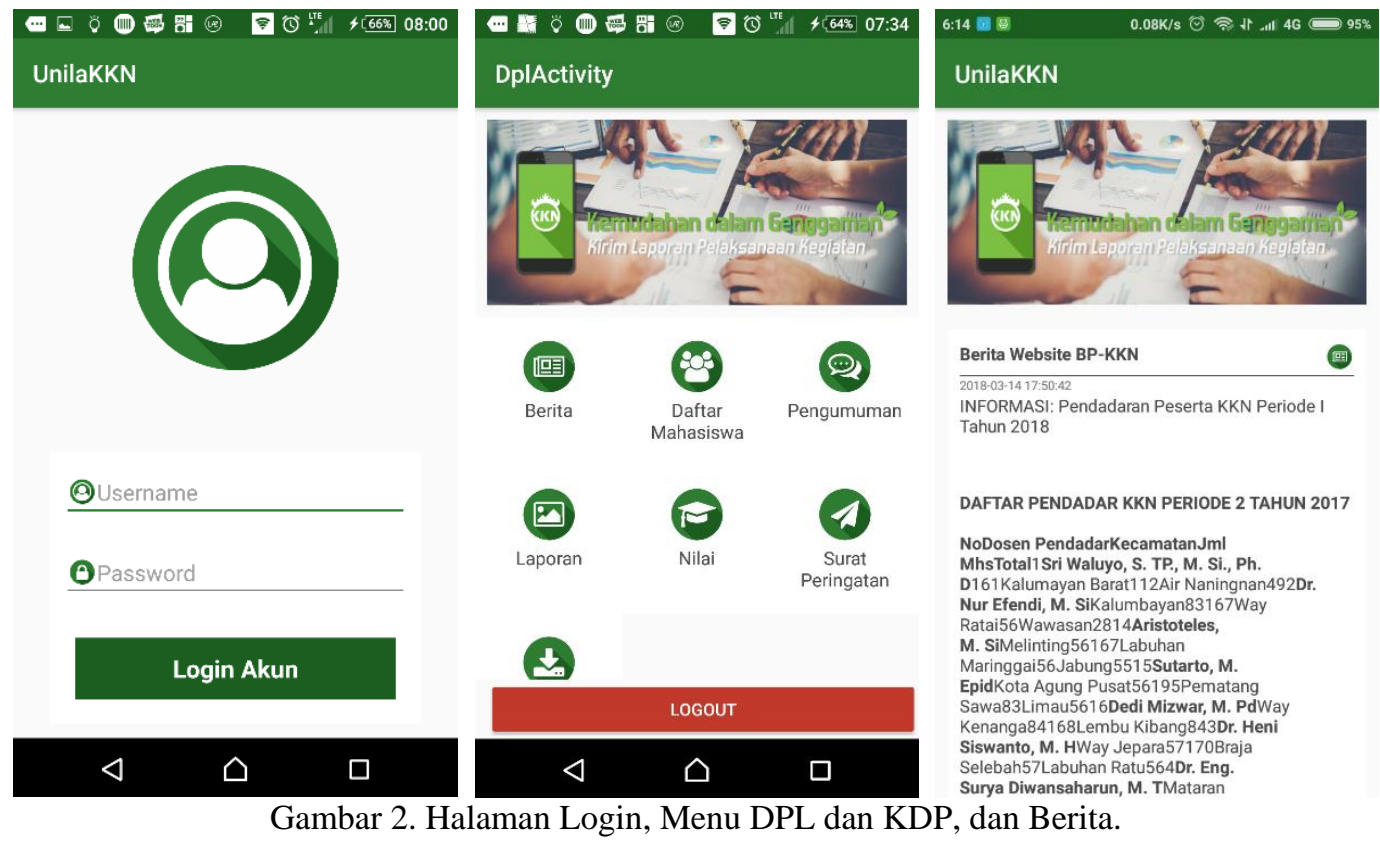


(C) Ilmu Komputer Unila Publishing Network all right reserve
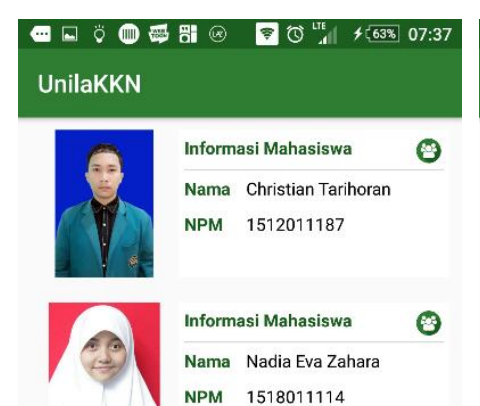

Informasi Mahasiswa

Nama Christian Tarihoran

NPM $\quad 1512011187$

\section{Informasi Mahasiswa} Nama Nadia Eva Zahara

NPM 1518011114

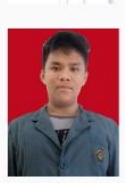

Informasi Mahasiswa

Nama Muhammad lqbal

NPM 1517021105

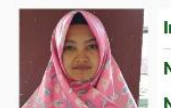

Informasi Mahasiswa

Nar

Meri Kusumawati

$\triangleleft$

$\checkmark$

$\square$

웅

$\mid$

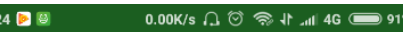

UnilaKKN

Form Kuisoner Jenis Bibir Sumbing den Langit-Langit

Form kuesioner harap dikumpulkan pada Korcam masing-masing, kemudian ke Subj: Kuesioner_BibirSumbing_NAMA KECAMATAN )

\section{Administrator}

2018-02-14 18:18:58

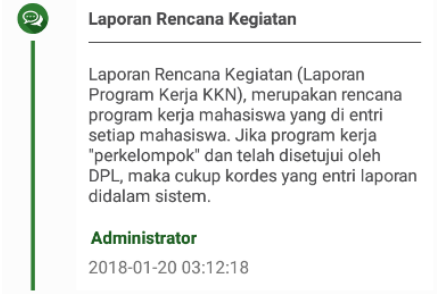

2018-01-20 03:12:18

Q Laporan Rencana Kegiatan

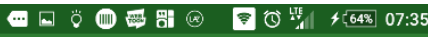

UnilakKN

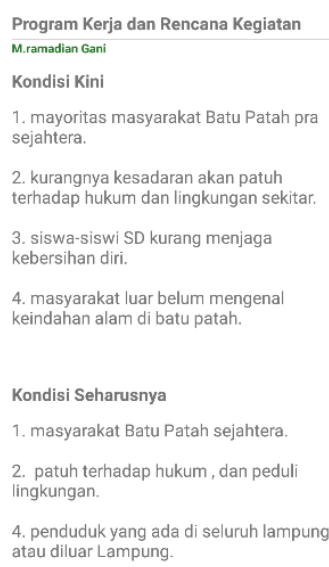

Program Kerja dan Rencana Kegiatan

M.ramadian Gani

Kondisi Kini

1. mayoritas masyarakat Batu Patah pra sejahtera.

2. kurangnya kesadaran akan patuh

terhadap hukum dan lingkungan sekitar.

3. siswa-siswi SD kurang menjaga

kebersihan diri.

4. masyarakat luar belum mengenal
keindahan alam di batu patah.

Kondisi Seharusnya

1. masyarakat Batu Patah sejahtera.

2. patuh terhadap hukum, dan peduli

ingkungan.

4. penduduk yang ada di seluruh lampung ar Lampung.

\section{$\triangleleft \quad 0 \quad \square$}

Gambar 3. Halaman Daftar Mahasiswa, Pengumuman, dan Laporan Mahasiswa
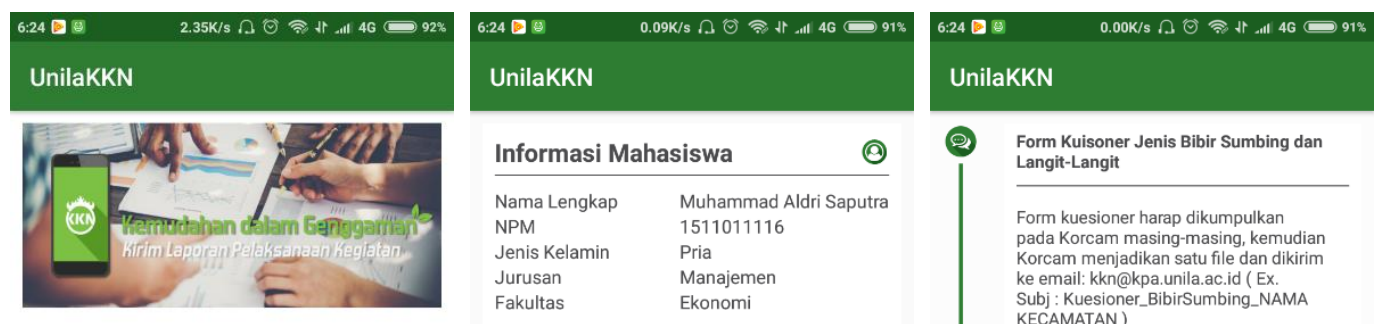

\begin{tabular}{ll} 
Informasi Mahasiswa \\
\hline Nama Lengkap & Muhammad Aldri Saputra \\
NPM & 1511011116 \\
Jenis Kelamin & Pria \\
Jurusan & Manajemen \\
Fakultas & Ekonomi
\end{tabular}

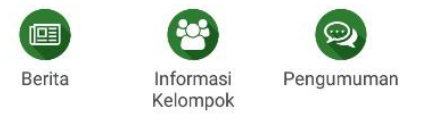

Lokasi Penempatan

28

Kabupaten Tanggamus $\begin{array}{ll}\text { Kecamatan } & \text { Ulubelu } \\ \text { Desa } & \text { Gunungtiga }\end{array}$

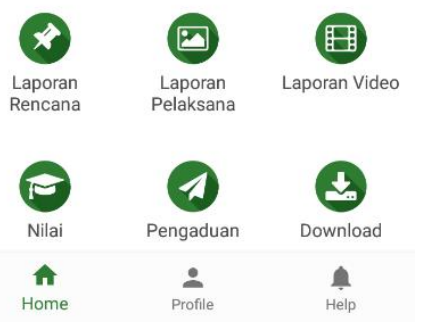

\begin{tabular}{ll} 
Informasi KDPL & () \\
\hline Nama Lengkap & Ir. Eka Kasymir, M.Si \\
NIP & 196306181988031003 \\
Jurusan & Agribisnis \\
Fakultas & Pertanian \\
No.Telp/HP & 08154020550 \\
& \\
Informasi DPL &
\end{tabular}

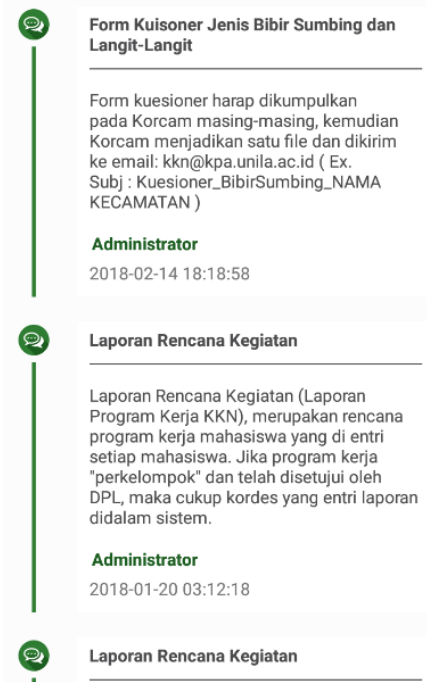

Gambar 4. Halaman Menu Mahasiswa, Informasi Kelompok dan Pengumuman 

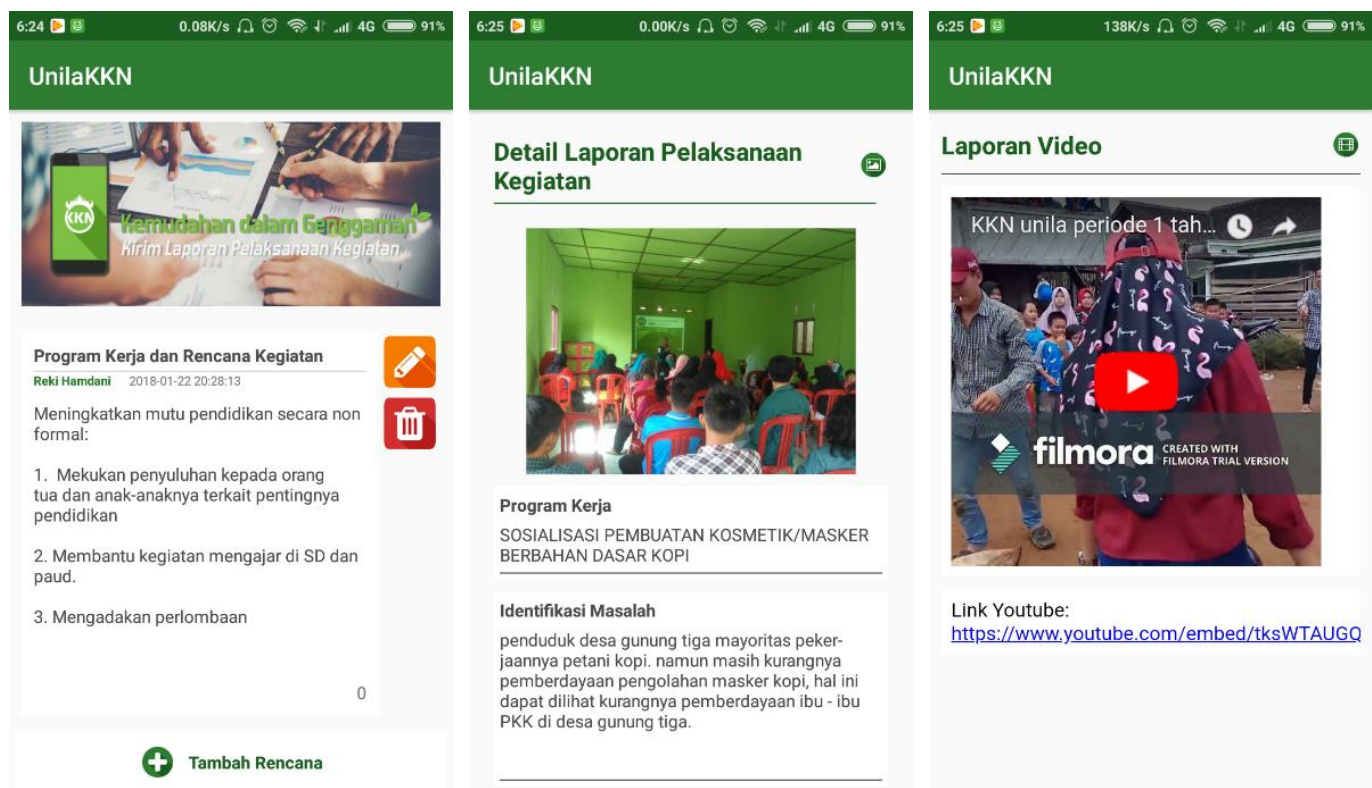

Link Youtube:

https://www.youtube.com/embed/tksWTAUGQ

Gambar 5. Halaman Laporan Rencana, Laporan Pelaksanaan dan Laporan Video.

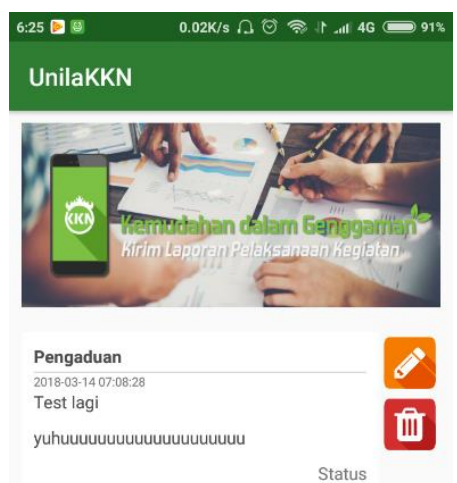

Status

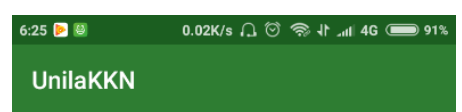

\begin{tabular}{ll} 
Informasi Mahasiswa \\
\hline Nama Lengkap & Muhammad Aldri Saputra \\
NPM & 1511011116 \\
Jenis Kelamin & Pria \\
Jurusan & Manajemen \\
Fakultas & Ekonomi
\end{tabular}

Nilai Mahasiswa

(1)

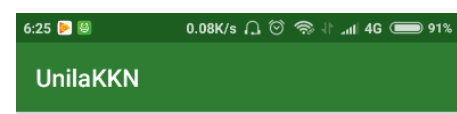

Download File Kebutuhan Selama KKN

1. Jurnal kegiatan harian dapat diunduh disini.

Jadwal kegiatan dapat diunduh disini.

3. Buku tamu diunduh disini.

4. Matrik program kerja dan rencana

kegiatan dapat diunduh disini.

5. Buku materi pembekalan KKN dapat

diunduh disini.

6. Buku panduan KKN Universitas Lampung

dapat diunduh disini.

(Tambah Pengaduan

Gambar 6. Halaman Pengaduan, Nilai Mahasiswa dan Download File.

\subsection{Pengujian Fungsi dari Menu Sistem}

Pengujian menu sistem dilakukan untuk mengetahui apakah fungsi menu yang diberikan berjalan dan berfungsi sesuai dengan yang diharapkan. Pengujian ini menggunakan beberapa kriteria yang sudah ditentukan seperti kelas uji, daftar pengujian, skenario uji, hasil yang diharapkan, dan hasil yang diperoleh.Pengujian ini dilakukan terhadap pengguna yaitu DPL, KDPL dan Mahasiswa.

\subsubsection{Koordinator Dosen Pembimbing Lapangan}

Pengujian yang dilakukan untuk Koordinator Dosen Pembimbing Lapangan (KDPL) mengujikan seluruh fungsi yang dapat dilakukan oleh KDPL. Fungsi -fungsi tersebut adalah mengentri pengumuman, mengentri nilai mahasiswa, dan mengentri surat peringatan. Pengujian fungsional sistem pada KDPL dapat dilihat pada Tabel 2. 
Tabel 2. Pengujian Fungsional Sistem Bagian Koordinator Dosen Pembimbing Lapangan

\begin{tabular}{|c|c|c|c|c|}
\hline \multirow[t]{2}{*}{ Kelas Uji } & \multirow{2}{*}{$\begin{array}{l}\text { Daftar } \\
\text { Pengujian }\end{array}$} & \multirow[t]{2}{*}{ Skenario Uji } & Hasil Yang & Hasil \\
\hline & & & \multicolumn{2}{|l|}{ Diharapkan } \\
\hline \multirow{7}{*}{$\begin{array}{l}\text { Fungsi Menu } \\
\text { Nilai }\end{array}$} & \multirow{7}{*}{$\begin{array}{l}\text { Pengujian entri } \\
\text { nilai mahasiswa }\end{array}$} & \multirow{2}{*}{$\begin{array}{l}\text { Melengkapi data } \\
\text { yang diisikan }\end{array}$} & \multirow{2}{*}{$\begin{array}{l}\text { Sistem } \\
\text { menyimpan data } \\
\text { nilai dan } \\
\text { ditampilkan }\end{array}$} & Berhasil \\
\hline & & & & $\begin{array}{l}\text { Sistem } \\
\text { menyimpan data } \\
\text { nilai dan } \\
\text { ditampilkan }\end{array}$ \\
\hline & & \multirow{5}{*}{$\begin{array}{l}\text { Mengosongkan } \\
\text { semua data yang } \\
\text { harus diisikan } \\
\text { atau salah satu }\end{array}$} & \multirow{5}{*}{$\begin{array}{l}\text { Sistem menolak } \\
\text { menyimpan data } \\
\text { dan memberikan } \\
\text { notifikasi bahwa } \\
\text { data harus diisi }\end{array}$} & Berhasil \\
\hline & & & & Sistem menolak \\
\hline & & & & menyimpan data \\
\hline & & & & dan memberikan \\
\hline & & & & $\begin{array}{l}\text { notifikasi bahwa } \\
\text { data harus diisi }\end{array}$ \\
\hline \multirow{10}{*}{$\begin{array}{l}\text { Fungsi Menu } \\
\text { Pengumuman }\end{array}$} & \multirow{10}{*}{$\begin{array}{l}\text { Pengujian entri } \\
\text { pengumuman }\end{array}$} & \multirow{5}{*}{$\begin{array}{l}\text { Melengkapi data } \\
\text { yang diisikan }\end{array}$} & \multirow{5}{*}{$\begin{array}{l}\text { Sistem } \\
\text { menyimpan data } \\
\text { dan } \\
\text { menampilkan } \\
\text { data yang telah } \\
\text { disimpan }\end{array}$} & Berhasil \\
\hline & & & & Sistem \\
\hline & & & & $\begin{array}{l}\text { menyimpan data } \\
\text { dan }\end{array}$ \\
\hline & & & & menampilkan \\
\hline & & & & $\begin{array}{l}\text { data yang telah } \\
\text { disimpan }\end{array}$ \\
\hline & & \multirow{5}{*}{$\begin{array}{l}\text { Mengosongkan } \\
\text { semua data yang } \\
\text { harus diisikan } \\
\text { atau salah satu }\end{array}$} & \multirow{5}{*}{$\begin{array}{l}\text { Sistem menolak } \\
\text { menyimpan data } \\
\text { dan memberikan } \\
\text { notifikasi bahwa } \\
\text { data harus diisi }\end{array}$} & Berhasil \\
\hline & & & & Sistem menolak \\
\hline & & & & menyimpan data \\
\hline & & & & dan memberikan \\
\hline & & & & $\begin{array}{l}\text { notifikasi bahwa } \\
\text { data harus diisi }\end{array}$ \\
\hline \multirow{10}{*}{$\begin{array}{l}\text { Fungsi Menu } \\
\text { Surat Peringatan }\end{array}$} & \multirow{10}{*}{$\begin{array}{l}\text { Pengujian entri } \\
\text { surat peringatan }\end{array}$} & \multirow{5}{*}{$\begin{array}{l}\text { Melengkapi data } \\
\text { yang diisikan }\end{array}$} & \multirow{5}{*}{$\begin{array}{l}\text { Sistem } \\
\text { menyimpan data } \\
\text { dan } \\
\text { menampilkan } \\
\text { data yang telah } \\
\text { disimpan }\end{array}$} & Berhasil \\
\hline & & & & Sistem \\
\hline & & & & menyimpan data \\
\hline & & & & $\begin{array}{l}\text { dan } \\
\text { menampilkan }\end{array}$ \\
\hline & & & & $\begin{array}{l}\text { data yang telah } \\
\text { disimpan }\end{array}$ \\
\hline & & Mengosongkan & Sistem menolak & Berhasil \\
\hline & & semua data yang & menyimpan data & Sistem menolak \\
\hline & & harus diisikan & dan memberikan & menyimpan data \\
\hline & & atau salah satu & notifikasi bahwa & dan memberikan \\
\hline & & & data harus diisi & $\begin{array}{l}\text { notifikasi bahwa } \\
\text { data harus diisi }\end{array}$ \\
\hline
\end{tabular}

\subsubsection{Dosen Pembimbing Lapangan}

Pengujian yang dilakukan untuk Dosen Pembimbing Lapangan (DPL) mengujikan seluruh fungsi yang dapat dilakukan oleh DPL. Fungsi -fungsi tersebut adalah mengentri pengumuman, mengentri nilai mahasiswa, dan mengentri surat peringatan. Pengujian fungsional sistem pada DPL dapat dilihat pada Tabel 3.

Tabel 3. Pengujian Fungsional Sistem Bagian Dosen Pembimbing Lapangan

\begin{tabular}{lllll}
\hline Kelas Uji & $\begin{array}{l}\text { Daftar } \\
\text { Pengujian }\end{array}$ & Skenario Uji & $\begin{array}{l}\text { Hasil Yang } \\
\text { Diharapkan }\end{array}$ & $\begin{array}{l}\text { Hasil } \\
\text { diperoleh }\end{array}$ \\
\hline $\begin{array}{l}\text { Fungsi Menu } \\
\text { Nilai }\end{array}$ & $\begin{array}{l}\text { Pengujian entri } \\
\text { nilai mahasiswa }\end{array}$ & Melengkapi data & $\begin{array}{l}\text { Sistem } \\
\text { menyimpan data } \\
\text { nilai dan } \\
\text { ditampilkan }\end{array}$ & $\begin{array}{l}\text { Berhasil } \\
\text { Sistem } \\
\text { menyimpan data } \\
\text { nilai dan } \\
\text { ditampilkan }\end{array}$ \\
\hline & & Mengosongkan & $\begin{array}{l}\text { Sistem menolak } \\
\text { menyimpan data }\end{array}$ & Berhasil \\
\hline
\end{tabular}




\section{(C) Ilmu Komputer Unila Publishing Network all right reserve}

\begin{tabular}{|c|c|c|c|c|}
\hline Kelas Uji & $\begin{array}{l}\text { Daftar } \\
\text { Pengujian }\end{array}$ & Skenario Uji & $\begin{array}{l}\text { Hasil Yang } \\
\text { Diharapkan }\end{array}$ & $\begin{array}{ll}\text { Hasil } & \text { Yang } \\
\text { diperoleh }\end{array}$ \\
\hline & & $\begin{array}{l}\text { harus diisikan } \\
\text { atau salah satu }\end{array}$ & $\begin{array}{l}\text { dan memberikan } \\
\text { notifikasi bahwa } \\
\text { data harus diisi }\end{array}$ & $\begin{array}{l}\text { Sistem menolak } \\
\text { menyimpan data } \\
\text { dan memberikan } \\
\text { notifikasi bahwa } \\
\text { data harus diisi }\end{array}$ \\
\hline \multirow[t]{2}{*}{$\begin{array}{l}\text { Fungsi Menu } \\
\text { Pengumuman }\end{array}$} & $\begin{array}{l}\text { Pengujian entri } \\
\text { pengumuman }\end{array}$ & $\begin{array}{l}\text { Melengkapi data } \\
\text { yang diisikan }\end{array}$ & $\begin{array}{l}\text { Sistem } \\
\text { menyimpan data } \\
\text { dan } \\
\text { menampilkan } \\
\text { data yang telah } \\
\text { disimpan }\end{array}$ & $\begin{array}{l}\text { Berhasil } \\
\text { Sistem } \\
\text { menyimpan data } \\
\text { dan } \\
\text { menampilkan } \\
\text { data yang telah } \\
\text { disimpan }\end{array}$ \\
\hline & & $\begin{array}{l}\text { Mengosongkan } \\
\text { semua data yang } \\
\text { harus diisikan } \\
\text { atau salah satu }\end{array}$ & $\begin{array}{l}\text { Sistem menolak } \\
\text { menyimpan data } \\
\text { dan memberikan } \\
\text { notifikasi bahwa } \\
\text { data harus diisi }\end{array}$ & $\begin{array}{l}\text { Berhasil } \\
\text { Sistem menolak } \\
\text { menyimpan data } \\
\text { dan memberikan } \\
\text { notifikasi bahwa } \\
\text { data harus diisi }\end{array}$ \\
\hline \multirow[t]{2}{*}{$\begin{array}{l}\text { Fungsi Menu } \\
\text { Surat Peringatan }\end{array}$} & $\begin{array}{l}\text { Pengujian entri } \\
\text { surat peringatan }\end{array}$ & $\begin{array}{l}\text { Melengkapi data } \\
\text { yang diisikan }\end{array}$ & $\begin{array}{l}\text { Sistem } \\
\text { menyimpan data } \\
\text { dan } \\
\text { menampilkan } \\
\text { data yang telah } \\
\text { disimpan }\end{array}$ & $\begin{array}{l}\text { Berhasil } \\
\text { Sistem } \\
\text { menyimpan data } \\
\text { dan } \\
\text { menampilkan } \\
\text { data yang telah } \\
\text { disimpan }\end{array}$ \\
\hline & & $\begin{array}{l}\text { Mengosongkan } \\
\text { semua data yang } \\
\text { harus diisikan } \\
\text { atau salah satu }\end{array}$ & $\begin{array}{l}\text { Sistem menolak } \\
\text { menyimpan data } \\
\text { dan memberikan } \\
\text { notifikasi bahwa } \\
\text { data harus diisi }\end{array}$ & $\begin{array}{l}\text { Berhasil } \\
\text { Sistem menolak } \\
\text { menyimpan data } \\
\text { dan memberikan } \\
\text { notifikasi bahwa } \\
\text { data harus diisi }\end{array}$ \\
\hline
\end{tabular}

\subsubsection{Mahasiswa}

Pengujian yang dilakukan untuk Mahasiswa mengujikan seluruh fungsi yang dapat dilakukan oleh Mahasiswa. Fungsi-fungsi tersebut adalah melihat berita, melihat info kelompok, melihat pengumuman, mengirim laporan dan melihat nilai. Pengujian fungsional sistem pada Mahasiswa dapat dilihat pada Tabel 4.

Tabel 4. Pengujian Fungsional Sistem Bagian Pengujian lihat pengumuman

\begin{tabular}{|c|c|c|c|c|}
\hline Kelas Uji & $\begin{array}{l}\text { Daftar } \\
\text { Pengujian }\end{array}$ & Skenario Uji & $\begin{array}{l}\text { Hasil Yang } \\
\text { Diharapkan }\end{array}$ & $\begin{array}{ll}\text { Hasil } & \text { Yang } \\
\text { diperoleh } & \end{array}$ \\
\hline $\begin{array}{l}\text { Fungsi Menu } \\
\text { Berita }\end{array}$ & $\begin{array}{l}\text { Pengujian lihat } \\
\text { berita }\end{array}$ & $\begin{array}{l}\text { Memilih menu } \\
\text { berita }\end{array}$ & $\begin{array}{l}\text { Sistem } \\
\text { menampilkan } \\
\text { berita website } \\
\text { KKN }\end{array}$ & $\begin{array}{l}\text { Berhasil } \\
\text { Sistem } \\
\text { menampilkan } \\
\text { berita website } \\
\text { KKN }\end{array}$ \\
\hline $\begin{array}{l}\text { Fungsi Menu } \\
\text { Informasi } \\
\text { Kelompok }\end{array}$ & $\begin{array}{l}\text { Pengujian lihat } \\
\text { info kelompok }\end{array}$ & $\begin{array}{l}\text { Memilih menu } \\
\text { info kelompok }\end{array}$ & $\begin{array}{l}\text { Sistem } \\
\text { menampilkan } \\
\text { informasi } \\
\text { kelompok KKN. }\end{array}$ & $\begin{array}{l}\text { Berhasil } \\
\text { Sistem } \\
\text { menampilkan } \\
\text { informasi } \\
\text { kelompok KKN. }\end{array}$ \\
\hline $\begin{array}{l}\text { Fungsi Menu } \\
\text { Pengumuman }\end{array}$ & $\begin{array}{l}\text { Pengujian lihat } \\
\text { pengumuman }\end{array}$ & $\begin{array}{l}\text { Memilih menu } \\
\text { pengumuman }\end{array}$ & $\begin{array}{l}\text { Sistem } \\
\text { menampilkan } \\
\text { pengumuman. }\end{array}$ & $\begin{array}{l}\text { Berhasil } \\
\text { Sistem } \\
\text { menampilkan } \\
\text { pengumuman. }\end{array}$ \\
\hline
\end{tabular}


(C) Ilmu Komputer Unila Publishing Network all right reserve

\begin{tabular}{|c|c|c|c|c|}
\hline Kelas Uji & $\begin{array}{l}\text { Daftar } \\
\text { Pengujian }\end{array}$ & Skenario Uji & $\begin{array}{l}\text { Hasil Yang } \\
\text { Diharapkan }\end{array}$ & $\begin{array}{ll}\text { Hasil } & \text { Yang } \\
\text { diperoleh } & \end{array}$ \\
\hline \multirow[t]{2}{*}{$\begin{array}{l}\text { Fungsi Menu } \\
\text { Laporan }\end{array}$} & $\begin{array}{l}\text { Pengujian kirim } \\
\text { laporan }\end{array}$ & $\begin{array}{l}\text { Melengkapi data } \\
\text { yang diisikan }\end{array}$ & $\begin{array}{l}\text { Sistem } \\
\text { menyimpan data } \\
\text { dan } \\
\text { menampilkan } \\
\text { data yang telah } \\
\text { disimpan }\end{array}$ & $\begin{array}{l}\text { Berhasil } \\
\text { Sistem } \\
\text { menyimpan data } \\
\text { dan } \\
\text { menampilkan } \\
\text { data yang telah } \\
\text { disimpan }\end{array}$ \\
\hline & & $\begin{array}{l}\text { Mengosongkan } \\
\text { data yang harus } \\
\text { diisikan }\end{array}$ & $\begin{array}{l}\text { Sistem menolak } \\
\text { menyimpan data } \\
\text { dan memberikan } \\
\text { notifikasi bahwa } \\
\text { data harus diisi }\end{array}$ & $\begin{array}{l}\text { Berhasil } \\
\text { Sistem menolak } \\
\text { menyimpan data } \\
\text { dan memberikan } \\
\text { notifikasi bahwa } \\
\text { data harus diisi }\end{array}$ \\
\hline $\begin{array}{l}\text { Fungsi Menu } \\
\text { Nilai }\end{array}$ & $\begin{array}{l}\text { Pengujian lihat } \\
\text { nilai KKN. }\end{array}$ & $\begin{array}{l}\text { Memilih menu } \\
\text { nilai. }\end{array}$ & $\begin{array}{l}\text { Sistem } \\
\text { menampilkan } \\
\text { informais nilai } \\
\text { mahasiswa. }\end{array}$ & $\begin{array}{l}\text { Berhasil } \\
\text { Sistem } \\
\text { menampilkan } \\
\text { informais nilai } \\
\text { mahasiswa. }\end{array}$ \\
\hline
\end{tabular}

\subsection{Analisis Hasil Kuisioner}

Berdasarkan pada interval kategori penilaian pada tabel diatas dapat disimpulkan dari pengujian spesifikasi pengguna Koordinator Dosen Pembimbing Lapangan didapatkan total rata-rata $86.8 \%$, menjadikan nilai tersebut masuk didalam kategori "Sangat Baik". Hasil pengujian spesifikasi pengguna untuk Dosen Pembimbing Lapangan didapatkan total rata-rata 58.07\%, yang menjadikan nilai termasuk kategori "Cukup Baik". Hasil pengujian spesifikasi pengguna untuk Mahasiswa didapatkan total rata-rata $76.30 \%$, yang menjadikan nilai termasuk kategori "Baik". Kesimpulan hasil pengujian tingkat kepuasan pengguna dapat dilihat pada tabel 5.

Tabel 5. Rekapitulasi Hasil Kuisioner Tingkat Kepuasan Pengguna

\begin{tabular}{lccc}
\hline \multicolumn{1}{c}{ Kategori } & KDPL & DPL & Mahasiswa \\
\hline Sangat Baik & $\mathbf{4 3 . 0 7 \%}$ & $\mathbf{2 9 . 2 3 \%}$ & $23.486 \%$ \\
Baik & $36.4 \%$ & $25.76 \%$ & $\mathbf{4 3 . 2 3 1 \%}$ \\
Cukup Baik & $7.05 \%$ & $13.46 \%$ & $26.711 \%$ \\
Kurang Baik & $0 \%$ & $0 \%$ & $4.4417 \%$ \\
Tidak Baik & $0 \%$ & $0.7 \%$ & $2.1296 \%$ \\
\end{tabular}

\section{Simpulan}

Berdasarkan penelitian yang telah dilakukan dapat disimpulkan beberapa hal sebagai berikut :

1. Telah berhasil dibangun sistem informasi KKN berbasis android yang dapat membantu pihak BP-KKN dalam mengelola informasi kepada mahasiswa.

2. Hasil pengujian tingkat kepuasan pengguna dapat disimpulkan pada Sistem Infomasi Kuliah Kerja Nyata Universitas Lampung Berbasis Android ini didapatkan Sangat Baik dengan ratarata 86.8\% dari Koordinator Dosen Pembimbing Lapangan sementara Cukup Baik didapatkan dari Dosen Pembimbing Lapangan dengan rata-rata 58.07\% dan bagian Mahasiswa tergolong Baik dengan rata-rata $76.30 \%$. 
(C) Ilmu Komputer Unila Publishing Network all right reserve

\section{Referensi}

[1] BP-KKN. 2016. Buku Panduan Kuliah Kerja Nyata (KKN). Lampung: Universitas Lampung.

[2] Permana, Danzen Hangga. 2017. Pengembangan Sistem Pelaporan Kegiatan KKN Berbasis Android [skripsi]. Lampung: Universitas Lampung.

[3] Wiranata, I. G. A. S. M., 2017. Mahasiswa \& Pembangunan Masyarakat. Bandar Lampung: BP-KKN.

[4] Hermawan, Stephanus., 2011, Mudah Membuat Aplikasi Android, Penerbit Andi, Yogyakarta.

[5] Nugroho, A. 2009. Rekayasa Perangkat Lunak Menggunakan UML \& Java. Yogyakarta: Andi Offset.

[6] Arief, M.Rudianto. 2011. Pemrograman Web Dinamis Menggunakan Php dan MySQL. Yogyakarta: ANDI.

[7] Pressman, R.S. 2010. Software Engineering: A Practitioner's Approach, $7^{\text {th }}$ Edition. New York: McGraw-Hill Companies, Inc.

[8] Jiang, F., Y. Lu. 2012. Software testing model selection research based on yinyang testing theory. In: IEEE Proceeding of International Conference on Computer Science and Information Processing (CISP), pp. 590-594.

[9] Busono, P. 2009. Testing \& Implementasi. Jakarta: Pusat Pengembangan Bahan Ajar UMB.

[10] Putra, 2014. Analisis Kualitas Layanan Website Btkp-Diy Menggunakan Metode Webqual 4.0. Jurnal Jarkom, pp. ISSN : 2338-6312. 